\section{Ethephon Concentrates and Advances Harvest for Limited Cluster Greenhouse Tomato Crops}

\author{
Logan S. Logendra, Jonathan G. Mun, Thomas J. Gianfagna, ${ }^{1}$ and \\ Harry W. Janes \\ Plant Biology Department, Rutgers-The State University of New Jersey, 59 \\ Dudley Road, New Brunswick, NJ 08901-8520
}

Additional index words. ethylene, ethrel, Lycopersicon esculentum

\begin{abstract}
Ethephon (2-chloroethylphosphonic acid) was applied to single cluster greenhouse tomato crops $(1000 \mathrm{ppm})$ at the green mature stage of fruit development or when $35 \%$ of the plants had fruits at the breaker stage. Fruits were harvested at the pink stage. Untreated fruit were harvested from 95 to 116 days after sowing whereas fruit from the green mature ethephon treatment were harvested from 92 to 102 days, three days earlier and with a reduction in the harvest window from 22 to 11 days. Fruit treated with ethephon at $35 \%$ breaker were harvested at the same time as untreated fruit, but harvest was completed after only 12 days. Fruit yield from the green mature ethephon treatment was reduced by about $30 \%$, but there was no significant difference in fruit yield as a result of ethephon treatment at $35 \%$ breaker. Fruit color, firmness and soluble solids were evaluated one and six days after harvest. Fruit firmness and soluble solids were unaffected by treatment; however, fruit from the ethephon treatments were significantly redder in color. In a second experiment, ethephon was applied at 500 or 1000 ppm when $100 \%$ of the plants had fruit at the breaker stage. Fruit were harvested over a 7-day time interval compared to untreated fruit that were harvested over 14 days, and there was a small but significant increase in fruit yield for the $1000 \mathrm{ppm}$ treatment. Both ethephon treatments also increased fruit soluble solids. For limited cluster tomato production systems, ethephon is effective in reducing the harvest window without loss in postharvest fruit quality.
\end{abstract}

Greenhouse grown tomatoes now account for more than $16 \%$ of the fresh market tomatoes in the U.S., up from only $1 \%$ in 1990 (DeGiglio, 2003; R. Cook, personal communication). Multiple cluster greenhouse tomato crops are usually grown hydroponically in bag culture with the stems trained on vertical and/or horizontal wires. There are usually two crops grown each year with harvests in the fall and spring. Continuous year-round production systems of one to three clusters per plant are being investigated, however, because they have the potential to increase crop profitability through increased yield and reduced costs for some cultural practices (Giniger et al., 1988; Logendra et al., 2001; McAvoy and Janes, 1988). For limited cluster systems, labor efficiency is improved since plants can be grown on transportable benches making pruning, spraying and harvesting the crop easier. Continuous production is possible since there is better utilization of natural and supplemental light in winter. The limited cluster system may also allow the use of growth regulators to reduce pruning or to promote fruit ripening since plants contain fruit at similar stages of development reducing unwanted side effects of treatment.

Ethephon is used on processing tomatoes to obtain a uniform earlier ripening crop in a single mechanical harvest (Murray, 2001). Since considerable leaf senescence results

Received for publication 6 Jan. 2004. Accepted for publication 8 Apr. 2004.

${ }^{1}$ E-mail gianfagna@aesop.rutgers.edu. from ethephon treatment it is unsuitable for the traditional greenhouse tomato crop that produces clusters of fruit sequentially over several months. However, for a limited cluster system, crop production time could be reduced by ethephon treatment if this treatment does not adversely affect fruit yield or postharvest quality. In this study we applied ethephon to single cluster tomato plants at two stages of fruit development and determined the effect on fruit yield, harvest dates, and fruit quality.

\section{Material and Methods}

Seeds ('Laura') were sown in rockwool (RW) plugs $(2.5 \times 2.5 \times 3.8 \mathrm{~cm})$, watered, and kept at $25^{\circ} \mathrm{C}$. After germination $(7 \mathrm{~d}$ after sowing) plants were irrigated with a nutrient solution containing the following elements: $\mathrm{N}$ (as $\mathrm{NO}_{3}$ ) at $172 \mathrm{mg} \cdot \mathrm{L}^{-1}, \mathrm{P}$ at $52 \mathrm{mg} \cdot \mathrm{L}^{-1}, \mathrm{~K}$ at $381 \mathrm{mg} \cdot \mathrm{L}^{-1}$, Ca at $177 \mathrm{mg} \cdot \mathrm{L}^{-1}, \mathrm{Mg}$ at $45 \mathrm{mg} \cdot \mathrm{L}^{-1}$, $\mathrm{Fe}$ at $0.7 \mathrm{mg} \cdot \mathrm{L}^{-1}, \mathrm{Mn}$ at $0.2 \mathrm{mg} \cdot \mathrm{L}^{-1}, \mathrm{Zn}$ at 0.04 $\mathrm{mg} \cdot \mathrm{L}^{-1}, \mathrm{Cu}$ at $0.01 \mathrm{mg} \cdot \mathrm{L}^{-1}, \mathrm{~B}$ at $0.13 \mathrm{mg} \cdot \mathrm{L}^{-1}$, and $\mathrm{Mo}$ at $0.06 \mathrm{mg} \cdot \mathrm{L}^{-1}$ with a $\mathrm{pH}$ of 5.5 to 6.5 and an $\mathrm{EC}$ of $1.0 \mathrm{mS} \cdot \mathrm{cm}^{-1}$. At $10 \mathrm{~d}$, seedlings were transplanted into RW cubes $(7.6 \times 7.6$ $\times 6.3 \mathrm{~cm})$ and grown on aluminum benches $(1.4 \times 5.0 \mathrm{~m})$ with an ebb and flood irrigation system. The greenhouse was maintained at 24 ${ }^{\circ} \mathrm{C}$ day $/ 20{ }^{\circ} \mathrm{C}$ night air temperature. Seedlings were spaced $30 \mathrm{~cm}$ apart on a thin sheet of rayon-polyester material that lined the bench. Plants received two irrigations per day with nutrient solution until $35 \mathrm{~d}$ when the irrigation regime was increased to 5 to 7 irrigations daily with an $\mathrm{EC}$ of $2.3 \mathrm{mS} \cdot \mathrm{cm}^{-1}$. The aerial portion of the plant was supported with two horizontal layers of galvanized wire mesh netting (12 gauge, with $15 \times 20$-cm grids) mounted on the benches at 30, and at either 60 or $90 \mathrm{~cm}$ above the bench top. At $45 \mathrm{~d}$ any side shoots that had developed were manually pruned and the plants were topped so that there were two leaves above the fruiting cluster. Pollination was accomplished by vibrating the flower clusters daily with a leaf-blower during the flowering period. If the outside natural light intensity was $<800 \mu \mathrm{mol} \cdot \mathrm{m}^{-2} \cdot \mathrm{s}^{-1}$, supplemental lighting was provided from high-pressure sodium lamps at an intensity of $80 \mu \mathrm{mol} \cdot \mathrm{m}^{-2} \cdot \mathrm{s}^{-1}$ for $16 \mathrm{~h}$ from 0500 to $2100 \mathrm{HR}$. Light integral measurements were made with quantum sensors located $1 \mathrm{~m}$ above the bench top and data were recorded with a datalogger (LI-1000; LI-COR, Lincoln, Nebr.).

Ethephon was applied with a hand sprayer until run-off, and fruit were harvested every other day at the pink stage. After rinsing in water, fruit color measurements were made on the equatorial surface using a chromameter (CR200; Minolta camera Co., Ltd., Osaka, Japan). Fruit firmness was measured as a compression force using a texture analyzer (TA.XT2; Stable Micro Systems, Surrey, U.K.) using a 1.25-cmdiameter spherical probe. Compression was applied to the fruit surface through a distance of $5 \mathrm{~mm}$ at a speed of $1 \mathrm{~mm} \cdot \mathrm{s}^{-1}$. Fruit were homogenized in a blender and soluble solids measured by refractometry using a Brix scale refractometer (Leica, Inc., Buffalo, N.Y.) Data were subjected to analysis of variance for a randomized complete-block experiment, with four plants/treatment in eight replicate blocks. Means were separated by LSD test.

\section{Results and Discussion}

Ethephon application to fruit at the mature green stage resulted in a significant advance and concentration of the harvest period. Fruit were harvested three $d$ earlier and for an 11-d harvest period compared to untreated fruit that were harvested over $22 \mathrm{~d}$ (Table 1). Fruit treated when $35 \%$ of the plants had fruit at the breaker stage were harvested at the same time as untreated fruit, but they were harvested over a 12-d interval. Fruit yield was unaffected by the ethephon treatment at $35 \%$ breaker, but the earlier treatment at the green mature stage resulted in a $30 \%$ yield reduction due to smaller average fruit size. This is in contrast with results from field grown tomato crops that are harvested once. Ethephon concentrated ripening and increased fruit yield by inducing more small fruits to ripen (Dostal and Wilcox, 1971; Splittstoesser and Vandemark, 1971). In the field studies employing a single harvest, these same fruit contribute to fruit yield whereas without ethephon treatment, they would be discarded. In our multiple harvest studies, the smaller younger fruit were induced to ripen before they had reached full size resulting in a yield reduction.

All fruit were harvested at the pink stage, and color intensity continued to increase during the postharvest period (Table 2). Arias et al. (2002) found a high correlation between the $a$ * 
Table 1. Effect of ethephon treatment at the green mature stage of fruit development or when $35 \%$ of the plants had fruit at the breaker stage on yield in a single cluster greenhouse tomato crop ('Laura')

\begin{tabular}{lcccc}
\hline $\begin{array}{l}\text { Stage of fruit } \\
\text { development }\end{array}$ & $\begin{array}{c}\text { Harvest window } \\
\text { (days after sowing) }\end{array}$ & Wt/plant $(\mathrm{g})$ & No./plant & Avg wt (g) \\
\cline { 2 - 5 } Control & $95-116$ & $1227 \mathrm{a}^{\mathrm{z}}$ & $5.1 \mathrm{a}$ & $248 \mathrm{a}$ \\
Green mature & $92-102$ & $869 \mathrm{~b}$ & $4.7 \mathrm{a}$ & $213 \mathrm{~b}$ \\
$35 \%$ Breaker & $95-106$ & $1098 \mathrm{a}$ & $4.9 \mathrm{a}$ & $243 \mathrm{a}$ \\
\hline
\end{tabular}

${ }^{\mathrm{z}}$ Mean separation within columns by LSD, $P \leq 0.05$.

Table 2. Effect of ethephon treatment at the green mature stage of fruit development or when $35 \%$ of the plants had fruit at the breaker stage on fruit color, firmness and soluble solids in a single cluster greenhouse tomato crop ('Laura').

\begin{tabular}{lccc}
\hline $\begin{array}{l}\text { Stage of fruit } \\
\text { development }\end{array}$ & $\begin{array}{c}\text { Color } \\
\left(\mathrm{a}^{*}\right)\end{array}$ & $\begin{array}{c}\text { Firmness } \\
(\mathrm{N} / \mathrm{mm})\end{array}$ & $\begin{array}{c}\text { Soluble solids } \\
\text { concn }(\%)\end{array}$ \\
\hline $\begin{array}{lll}\text { 1 d Postharvest } \\
\text { Control }\end{array}$ & $25 \mathrm{f}^{\mathrm{y}}$ & $1.27 \mathrm{a}$ & $5.6 \mathrm{~b}$ \\
Green mature & $28 \mathrm{~d}$ & $1.29 \mathrm{a}$ & $5.6 \mathrm{~b}$ \\
$\quad$ Breaker & $26 \mathrm{e}$ & $1.23 \mathrm{a}$ & $5.6 \mathrm{~b}$ \\
6 d Postharvest & $31 \mathrm{c}$ & $0.91 \mathrm{~b}$ & $5.4 \mathrm{~b}$ \\
$\quad$ Control & $34 \mathrm{a}$ & $0.99 \mathrm{~b}$ & $6.0 \mathrm{a}$ \\
$\quad$ Green mature & $32 \mathrm{~b}$ & $0.96 \mathrm{~b}$ & $5.5 \mathrm{~b}$ \\
\hline Breaker & &
\end{tabular}

${ }^{\mathrm{z}}$ Fruit were harvested at the pink stage.

${ }^{\mathrm{y}}$ Mean separation within columns by LSD, $P \leq 0.05$.

Table 3. Effect of two rates of ethephon applied at the breaker stage of fruit development on yield and postharvest fruit quality in a single cluster greenhouse tomato crop ('Laura').

\begin{tabular}{|c|c|c|c|c|c|c|}
\hline \multirow[b]{2}{*}{ Treatment } & \multirow[b]{2}{*}{$\begin{array}{l}\text { Harvest window } \\
\text { (days after sowing) }\end{array}$} & \multicolumn{5}{|c|}{ Fruit $^{\mathrm{z}}$} \\
\hline & & $\begin{array}{l}\text { Wt/plant } \\
\text { (g) }\end{array}$ & $\begin{array}{l}\text { No./ } \\
\text { plant }\end{array}$ & $\begin{array}{l}\text { Avg wt } \\
(g)\end{array}$ & $\begin{array}{l}\text { Firmness }^{y} \\
(\mathrm{~N} / \mathrm{mm})\end{array}$ & $\begin{array}{c}\text { Soluble solids } \\
\text { concn }^{\mathrm{y}}(\%)\end{array}$ \\
\hline Control & $102-115$ & $1241 b^{x}$ & $4.4 \mathrm{a}$ & $248 \mathrm{a}$ & $0.90 \mathrm{a}$ & $5.5 \mathrm{~b}$ \\
\hline Ethephon (500 ppm) & $102-108$ & $1298 \mathrm{ab}$ & $5.0 \mathrm{a}$ & $279 \mathrm{a}$ & $0.96 \mathrm{a}$ & $6.1 \mathrm{a}$ \\
\hline Ethephon $(1000 \mathrm{ppm})$ & $102-108$ & $1419 \mathrm{a}$ & $5.4 \mathrm{a}$ & $284 \mathrm{a}$ & $0.88 \mathrm{a}$ & $6.2 \mathrm{a}$ \\
\hline
\end{tabular}

${ }^{\mathrm{z}}$ Fruit were harvested at the pink stage.

y $8 \mathrm{~d}$ after harvest.

${ }^{\mathrm{x}}$ Mean separation within columns by LSD, $P \leq 0.05$.

color meter value for red color and the lycopene content of the fruit. Ethephon treatments resulted in higher red color measurements at both test dates. In contrast, there were no differences between treatments for fruit firmness at either date, although all fruit lost about $25 \%$ of firmness between the test dates. Soluble solids were generally unaffected by either treatment or date in this experiment.

In a second experiment (Table 3), ethephon treatments were made when all plants had fruit at the breaker stage. Fruit harvest was concentrated and there was an increase in fruit yield at the $1000 \mathrm{ppm}$ rate. Untreated plants contained a number of small green fruit that were discarded at the end of the experiment, whereas most of these fruits ripened on the ethephon treated plants contributing to the increase in yield. Soluble solids content of the fruit was significantly increased by ethephon treatment in this experiment. Variable effects on soluble solids have been reported previously. Iwahori and Lyons (1970) found that the soluble solids in tomato fruit increased between breaker and full color development with ethephon, and Ohta et al. (1992) found that Brix values increased after ethephon treatment to cherry tomatoes. For processing tomatoes, however, there is generally little effect of ethephon on soluble solids (Murray, 2001). Tomato fruit continue to increase in size even during the early stages of fruit ripening (Atta-Aly et al., 1999), and soluble solids may increase in tomato if there is continued translocation of sugars into the fruit, or if there is a more complete breakdown of starch to sugars. Ethephon may affect assimilate translocation to fruit by inducing leaf senescence in older leaves, which are probably only marginal source leaves during the time of fruit ripening, and remobilizing the carbohydrates to the fruit. Ethephon may also affect the regulation of genes involved in carbohydrate metabolism during ripening such as the invertases (Davies et al., 1990), which may increase soluble solids content directly, or indirectly, via enhanced unloading of sucrose from the phloem into fruit (Roitsch et al., 1995).

For limited cluster greenhouse production systems, ethephon can be a useful plant growth regulator to concentrate and advance harvest, and may in some cases increase postharvest fruit quality.

\section{Literature Cited}

Atta-Aly, M.A., G.S. Riad, Z.S. El-Lacheene, and A.S.El-Beltagy. 1999. Early application of ethrel extends tomato fruit cell division and increases fruit size and yield with ripening delay. J. Plant Growth Regulat.18:15-24.

Arias, R., T.C. Lee, L. Logendra, and H.W. Janes. 2000. Correlation of lycopene measured by HPLC with the $\mathrm{L}^{*}, \mathrm{a}^{*}, \mathrm{~b}^{*}$ color readings of a hydroponic tomato and the relationship of maturity with color and lycopene content. J. Agr. Food Chem. 48:1697-1702.

Davies, K. M., G.E. Hobson, and D. Grierson. 1990. Differential effect of silverions on the accumulation of ripening-related mRNAs in tomato fruit. J. Plant Physiol. 135:708-713.

De Giglio, M.A. 2003. Growth of the greenhouse fresh tomato market in the USA. Acta Hort. 611:91-92.

Dostal,H.G. and G.E. Wilcox. 1971. Chemical regulation of fruit ripening of field-grown tomatoes with 2-chloroethylphosphonic acid. J. Amer. Soc. Hort. Sci. 96:656-660.

Giniger, M.S., R.J. McAvoy, G.A. Giacomelli, and H.W. Janes. 1988. Computer simulation of a single truss tomato cropping system. Trans. Amer. Soc. Agr. Eng. 31:1176-1179.

Iwahori, S. and J.M. Lyons. 1970. Maturation and quality of tomatoes with pre-harvest treatments of 2-chloroethylphosphonic acid. J. Amer. Soc. Hort. Sci. 95:88-91.

Logendra, L.S., T.J. Gianfagna, D.R. Specca, and H.W. Janes. 2001. Limited cluster production systems for the greenhouse tomato: cluster number, leaves above the cluster, and plant spacing affect crop yield. HortScience 86:893-896.

McAvoy, R.J. and H.W. Janes. 1988. Alternative production strategies for greenhouse tomatoes using supplemental lighting. Scientia Hort. 35:161-166.

Murray, M. 2001. Using ethephon effectively for enhancing early-season processing tomato fruit maturity in California. Acta Hort. 542:373-376

Ohta, K., N. Ito, T. Hosoki, and K. Endo. 1992. Studies on whole truss-harvesting method of cherry tomato by ethrel and abscisic acid treatments. J. Jpn. Soc. Hort. Sci. 61:49-53.

Roitsch, T., M. Bittner, and D.E. Godt. 1995. Induction of apoplastic invertase of Chenopodium rubrum by $\mathrm{D}$-glucose and a glucose analog and tissue-specific expression suggest a role in sink-source regulation. Plant Physiol. 108:285-294.

Splittstoesser, W.E. and J.S. Vandemark. 1971. Maturation, fruit size and yield of tomatoes treated before harvest with 2-chloroethylphosphonic acid. J. Amer. Soc. Hort. Sci. 96:564-567. 